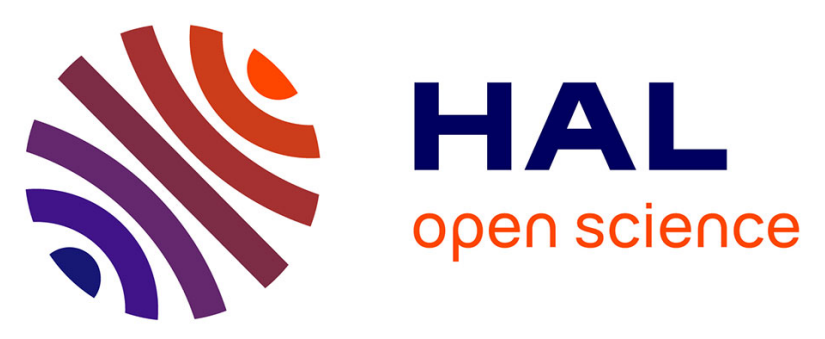

\title{
The variation of lateral and posterior coverage of the femoral head by the acetabulum during walking influences stability during gait
}

Chris Labaki, Aya Karam, Georges Mjaess, Ziad Bakouny, Aren Joe Bizidikian, Fares Yared, Joeffroy Otayek, Wafa Skalli, Ismat Ghanem, Ayman Assi

\section{To cite this version:}

Chris Labaki, Aya Karam, Georges Mjaess, Ziad Bakouny, Aren Joe Bizidikian, et al.. The variation of lateral and posterior coverage of the femoral head by the acetabulum during walking influences stability during gait. Gait \& Posture, 2018, 65 (S1), pp.139-141. 10.1016/j.gaitpost.2018.06.090 . hal-02561805

\section{HAL Id: hal-02561805 \\ https://hal.science/hal-02561805}

Submitted on 4 May 2020

HAL is a multi-disciplinary open access archive for the deposit and dissemination of scientific research documents, whether they are published or not. The documents may come from teaching and research institutions in France or abroad, or from public or private research centers.
L'archive ouverte pluridisciplinaire HAL, est destinée au dépôt et à la diffusion de documents scientifiques de niveau recherche, publiés ou non, émanant des établissements d'enseignement et de recherche français ou étrangers, des laboratoires publics ou privés. 


\title{
O 063 - The variation of lateral and posterior coverage of the femoral head by the acetabulum during walking influences stability during gait
}

\author{
C. Labaki ${ }^{\mathrm{a}}$, A. Karam ${ }^{\mathrm{a}}$, G. Mjaess ${ }^{\mathrm{a}}$, Z. Bakouny ${ }^{\mathrm{a}}$, A.J. Bizdikian ${ }^{\mathrm{a}}$, F. Yared ${ }^{\mathrm{a}}$, J. Otayek ${ }^{\mathrm{a}}$, W. Skalli ${ }^{\mathrm{b}}$, \\ I. Ghanem ${ }^{\text {a }}$, A. Assi ${ }^{\mathrm{a}, \mathrm{b}, *}$ \\ ${ }^{a}$ Faculty of Medicine - University of Saint-Joseph, Laboratory of Biomechanics and Medical Imaging, Beirut, Lebanon \\ ${ }^{\mathrm{b}}$ Arts et Métiers ParisTech, Institut de Biomécanique Humaine Georges Charpak, Paris, France
}

\section{Introduction}

Gait balance, assessed by the angle formed between the line joining the center-of-mass (COM) to the center-of-pressure (COP) and the vertical during gait, has been shown to be related to skeletal-postural and anthropometric parameters [1]. Although skeletal-postural parameters are measured on standing radiographs, they are known to vary during gait. There are currently no studies evaluating how the variations of skeletal-postural parameters during gait influence subject's balance during walking.

\section{Research question}

How does the variation of skeletal-postural parameters during gait influence subject's balance during walking?

\section{Methods}

72 asymptomatic subjects (age: $28.6 \pm 11$ years [18-59], 29F) underwent 3D gait analysis [2] with additional markers on the thighs and shanks. The COM-COP angle with the vertical was calculated in both the frontal and sagittal planes during the gait cycle [3] (Fig. 1). Subjects then underwent low-dose full-body biplanar X-rays with the markers still in place. 3D reconstructions were obtained for the spine, pelvis and lower limbs. 3D bones were registered at each frame of the gait cycle [4]. A new technique developed for this study, utilizing finite element modelling, was used to reduce soft tissue artefacts. Skeletalpostural parameters were then computed during the gait cycle, using the 3D registered bones, at each time frame (Fig. 2); mean, minimum, maximum and ROM were calculated on the waveforms during the gait cycle. In order to determine which varying skeletal-postural parameter during gait determined the variation of the COM-COP angles, univariate analysis (Pearson's correlation) followed by a multivariate analysis (stepwise-multiple-linear-regression models) were computed; COMCOP parameters were the dependant variables and varying skeletalpostural parameters during gait were the independent variables.

\section{Results}

Minimum $\left(-14.2 \pm 3.4^{\circ}\right)$ and average $\left(3.1 \pm 1.6^{\circ}\right)$ of the sagittal COM-COP angle were found to be determined by the minimum of the posterior coverage (post_cov) of the femoral head by the acetabulum during gait $(\beta=0.40 ; R 2=0.16 ; p=0.003$ and $\beta=0.32 ; R 2=0.1$; $\mathrm{p}=0.001$, respectively). ROM $\left(33.9 \pm 5.1^{\circ}\right)$ and maximum $\left(19.7 \pm 2.8^{\circ}\right)$ of the sagittal COM-COP angle were found to be related to the ROM ( $\beta=0.29 ; \mathrm{R} 2=0.09 ; \mathrm{p}=0.03$ ) and maximum $(\beta=0.34$; $\mathrm{R} 2=0.11 ; \mathrm{p}=0.006)$ of the acetabular abduction during gait, respectively. ROM of the frontal COM-COP angle $\left(8.8 \pm 2.51^{\circ}\right)$ was found to be determined by the average of the post_cov $(\beta=0.51$; $\mathrm{R} 2=0.26 ; \mathrm{p}=0.004$ ) during gait.

\section{Discussion}

This is the first study to evaluate how the variation of skeletalpostural parameters during walking influences the stability during gait (Fig. 3). A less pronounced posterior coverage of the acetabulum during gait predisposes to more instability by decreasing the minimum COMCOP angle; a more pronounced acetabular abduction (decreased lateral coverage) during gait predisposes to more instability by increasing the ROM and the maximum of the COM-COP angle. Therefore, gait instability in the sagittal plane seems to be influenced by the variation of the posterior and lateral coverage of the femoral head by the acetabulum during walking.

\footnotetext{
* Corresponding author.

E-mail address: ayman.assi@usj.edu.lb (A. Assi).
} 

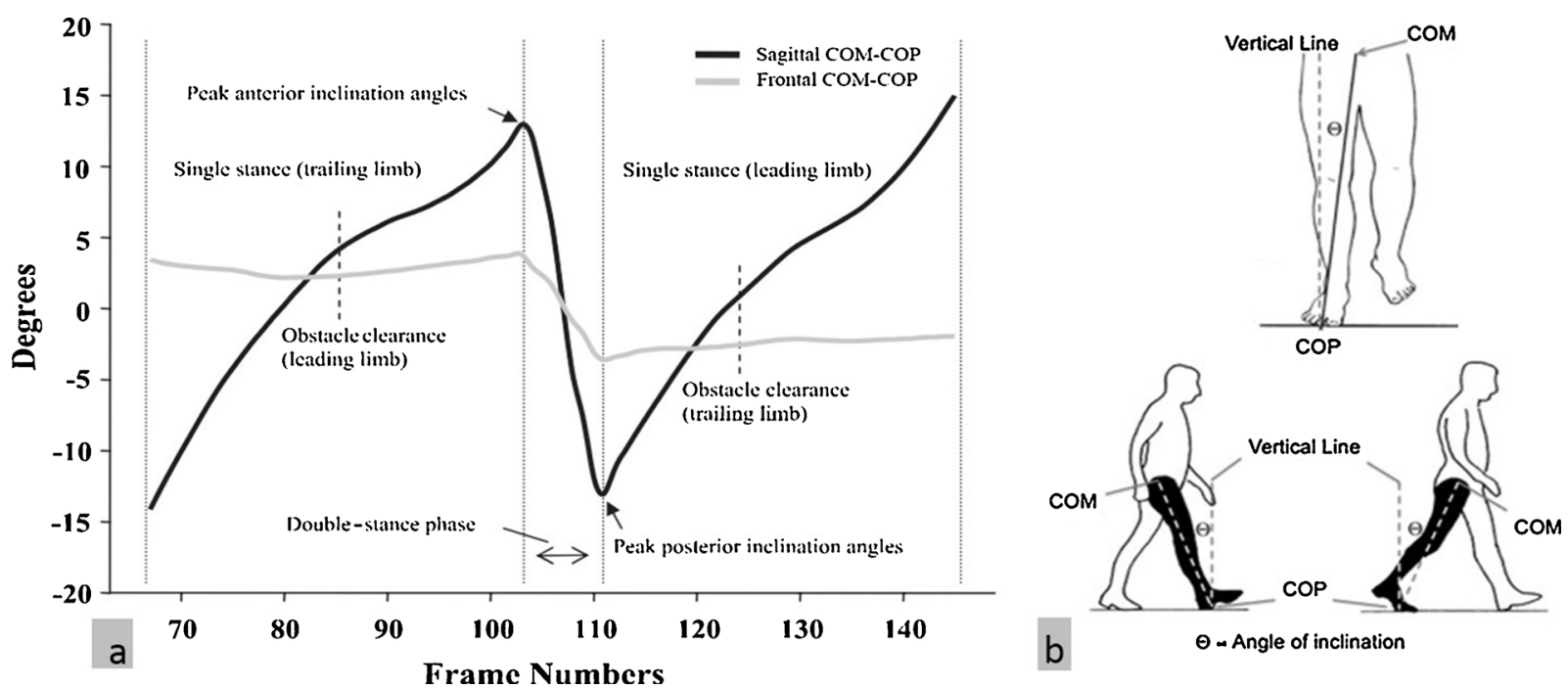

Fig. 1. a) Frontal and sagittal COM-COP (Center Of Mass-Center Of Pressure) diagram computed during the gait cycle; b) Measurement methods of the frontal and sagittal COM-COP during the gait cycle.

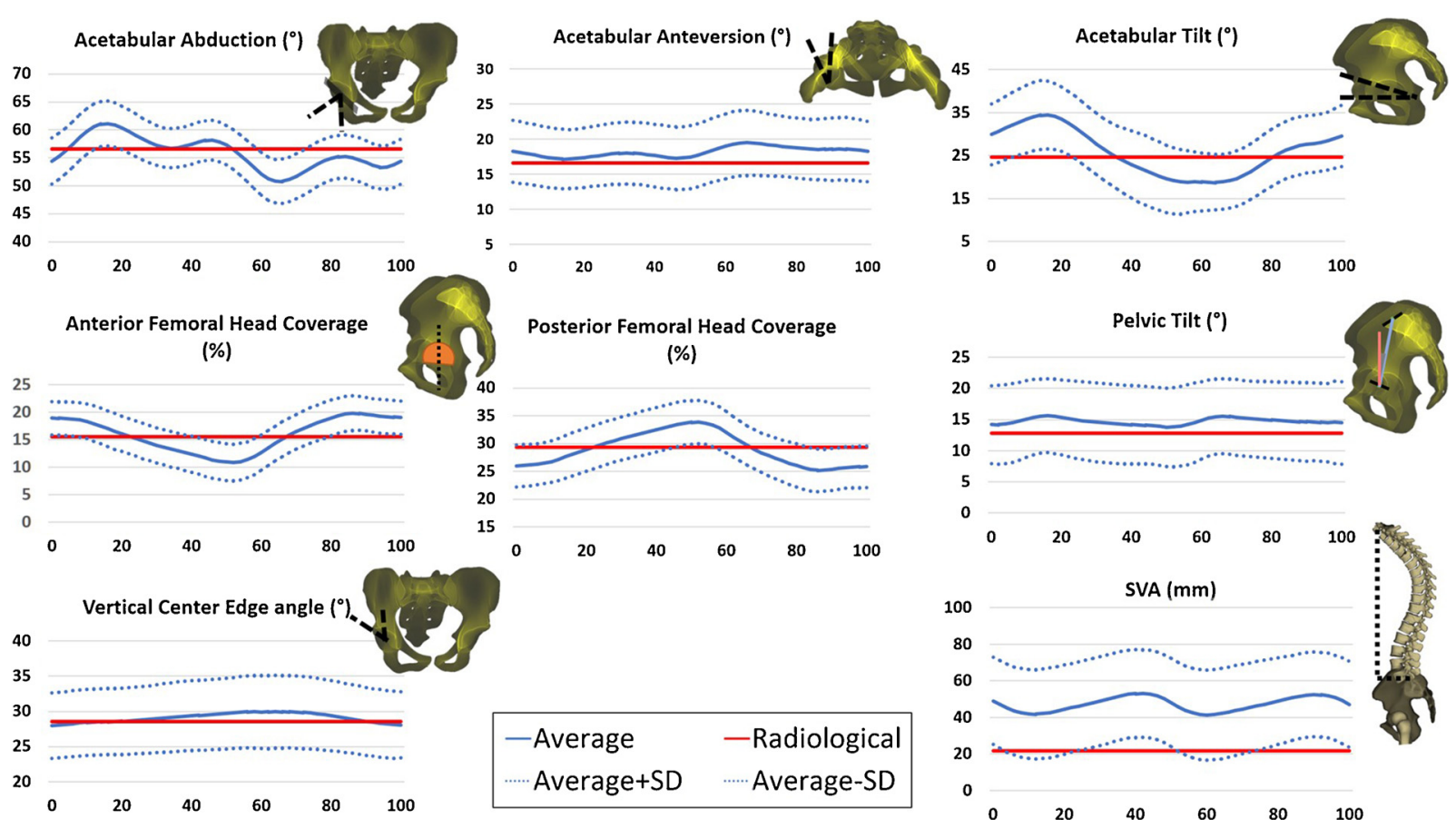

Fig. 2. 3D skeletal-postural parameters computed during the gait cycle. 

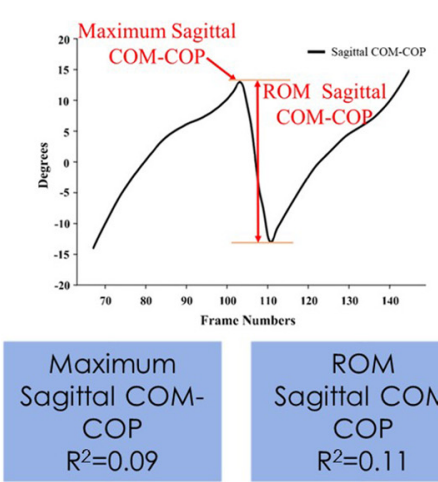

\section{$\beta=0.29$}

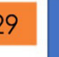

\section{Maximum \\ Acetabular \\ Abduction}
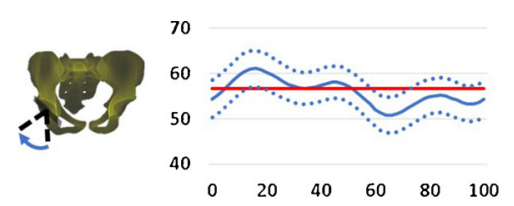

ROM

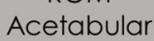

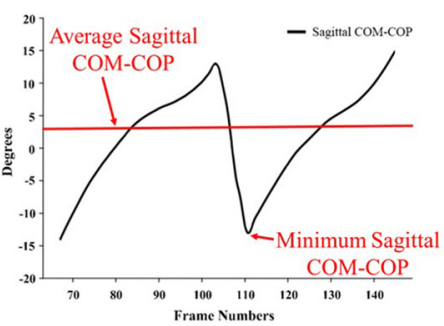
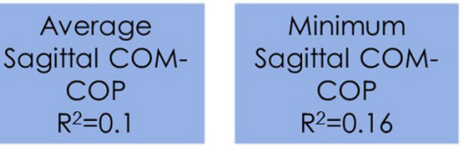

$\beta=0.32$
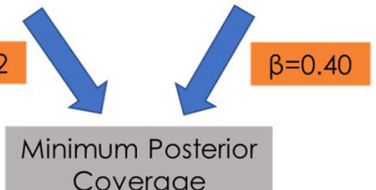

$$
\text { Coverage }
$$
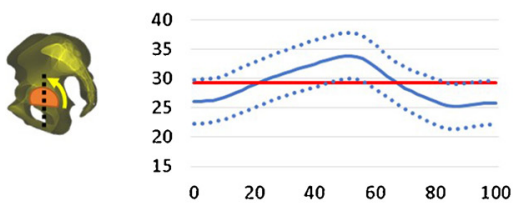

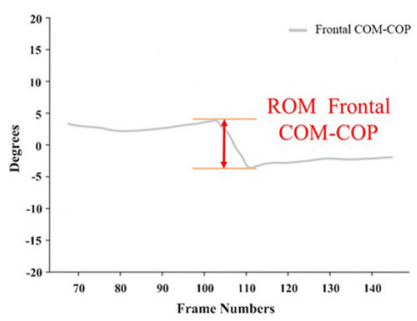

ROM

Frontal COM-

COP

$\mathrm{R}^{2}=0.26$

\section{$\beta=0.51$}

Average Posterior Coverage
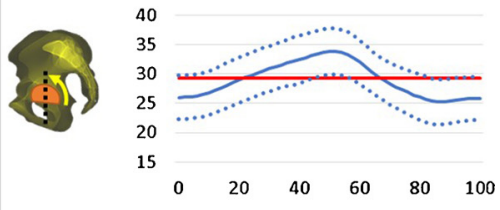

Fig. 3. Determinants of frontal and sagittal COM-COP variation among skeletal-postural parameters computed during the gait cycle.

\section{References}

[1] Bakouny et al., Gait and Posture, 2017.
[2] Davis et al., Human Movement Science, 1991.

[3] Paul et al., Gait and Posture, 2014.

[4] Söderkvist et al., Journal of Biomechanics, 1993. 